
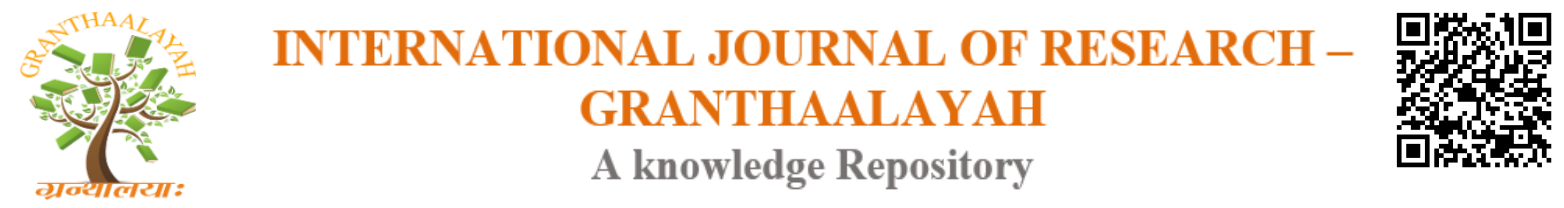

Management

\title{
MEDIATIONG ROLE OF ORGANIZATIONAL COMMITMENT IN DEVELOPING EMPLOYEE PERFORMANCE- (STUDY IN REGIONAL SECRETARIAT OF BLORA REGION, CENTRAL JAVA, INDONESIA)
}

\author{
Evi Susiyanti Estiningtyas ${ }^{1}$, Susetyo Darmanto ${ }^{2}$ \\ ${ }^{1,2}$ Fakultas Ekonomika dan Bisnis, Universitas 17 Agustus 1945 Semarang
}

\begin{abstract}
The purpose of this study is to analyse the effect of locus of control and self-efficacy on the employee performance of Regional Secretariat of Blora Regency with organizational commitment as intervening variable. The data used is primary data by taking samples of employees in the Regional Secretariat of Blora Regency as many as 62 respondents. Path analysis with SPSS 22 statistical program is used for data analysis. Locus of control and selfefficacy had a positive and significant effect on organizational commitment. Self-efficacy also had positive effect on employed performance. Despite, Locus of control had negative effect on employee performance. Organizational commitment is also proven to have a mediating role, so it can be a factor that plays a role in encouraging employee performance improvement.
\end{abstract}

Keywords: Locus of Control; Self Efficacy; Organizational Commitment; Employee Performance.

Cite This Article: Evi Susiyanti Estiningtyas, and Susetyo Darmanto. (2018). "MEDIATIONG ROLE OF ORGANIZATIONAL COMMITMENT IN DEVELOPING EMPLOYEE PERFORMANCE- (STUDY IN REGIONAL SECRETARIAT OF BLORA REGION, CENTRAL JAVA, INDONESIA)." International Journal of Research - Granthaalayah, 6(2), 283-291. https://doi.org/10.5281/zenodo.1194727.

\section{Introduction}

Public organizations need employees who are willing to work hard for the benefit of the organization and are fully involved in achieving organizational goals and survival (Meyer and Herscovitch, 2001). Achieving optimal organizational goals requires optimal, targeted and planned human resource management (Mowday, Porter, \& Steers, 1982). The above also applies to government organizations, one of them is the Secretariat Department of Blora Regency. The Secretariat Department is one of the regional apparatus organization which is domiciled as the coordinator for other regional apparatus has a strategic role in achieving the objectives to be achieved by Local Government. The Secretariat Department of Blora Regency has 9 sections with a total of 120 employees. The general condition of personnel shows that the discipline aspect, technical ability, effectiveness and efficiency of performance are still not as expected. 
According to Hessel (2007: 178) the factors that affect organizational performance are motivation, organizational culture, compensation, Locus of Control, job satisfaction, discipline, work environment and organizational commitment. Organizational commitment is defined as the relative strength of a worker's identification with and involvement in an organization (Porter, Steers, Mowday, \& Boulian, 1974); (Tett \& Meyer, 1993). In the era of increasingly fierce competition and increasingly limited resources, efforts aimed at increasing the organization's commitment to the workforce are the key challenges that management must respond to from an organization (Brown \& Peterson, 1993) (Robbins, 1993). Given the importance of organizational commitment to the success of the organization to build its competitive advantage, the organization certainly needs to understand and look for factors that can explain the low level of organizational commitment of the members of the organization.

One factor that greatly influences the worker organization's commitment is the personality aspect of the worker ((Patten, 2005). Personality is defined as a set of stable characteristics that affect one's behavior (Macik-Frey, Quick, \& Nelson, 2007). According to (Allport, 1961) personality is a dynamic organization in a psychological psychology that determines people to adapt to their environment. From several characteristics of personality, there are very important personality among them namely locus of control ((Rotter, 1966),(Hyatt \& Prawitt, 2001) and self-efficacy (Entrialgo, Fernández, \& Vázquez, 2000). Personality Traits or personality traits in the workforce have been considered an important factor in the study of specific personality-related behaviors to predict work performance. Personality explains whether a person will perform certain jobs, compared to others (Beer \& Brooks in Awadh, 2011)

The research of (Taormina \& Lao, 2007), (Darmanto, 2012) states that the success of a business is determined by individual characteristics. Individual characteristics are inherent in the individual that can be volatile or stable over time. Individual characteristics that may vary due to a particular situation or experience. Examples are self-efficacy and self-esteem formed by experience and learning factors. On the other hand, individual characteristics that are stable formed because it is already attached to the individual. Examples are personality and locus of control. (Hisrich, Langan-Fox, \& Grant, 2007), states that some individual characteristics such as self-efficacy, self-esteem and locus of control have an important role to the success of a business's performance (Darmanto, 2012), (Susetyo \& Lestari, 2014) suggested that individual characteristics such as personality, motivation, self-efficacy, locus of control and risk taking can determine an entrepreneur's success in business management.

Several previous studies have also linked performance with job satisfaction, psychological factors namely locus of control and self-efficacy, and organizational commitment, there is still a difference (research gap). According to Su-Ming Huang \& Wen-Hsiang Lai (2014) locus of control has a significant influence on performance, whereas according to (ISWARI, 2013) locus of control has no effect on performance.

Based on the background, the research problem proposed is: how is the influence of locus of control and self-efficacy on the performance officer of the Regional Secretariat of Blora Regency with organizational commitment as intervening variable. 
Based on the research gap and research problems, the proposed hypothesis is as follows: (H1) locus of control has a positive and significant effect on organizational commitment; (H2) selfefficacy has a significant positive effect on organizational commitment; (H3) locus of control has a positive and significant effect on employee performance ; $(\mathrm{H} 4)$ self-efficacy has a positive and significant effect on employee performance; (H5) organizational commitment has a positive and significant effect on employee performance.

\section{Method}

\subsection{Population and Sample}

The population of the research is employee in the Secretariat of Blora Regency amounting to 120. Respondents of 62 were determined by Slovin formula

\subsection{Data Analysis}

Path analysis model with multiple linear regression approach is used for data analysis in this research. The relationship of Locus of control and Self efficacy to employee performance with intervening variable of Organizational commitment can be explained in Figure 1.

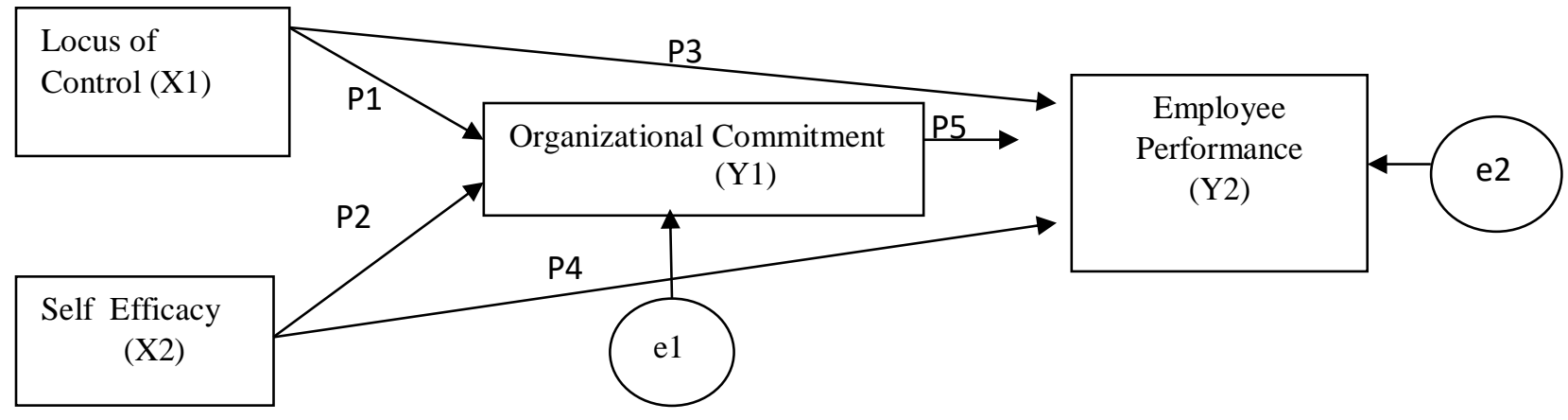

Figure 1: Path Analysis

\section{Result and Discussion}

\subsection{Validity and Reliability Test}

Based on the validity test to test how well the research instruments and concepts should be measured, all known valid and reliable instruments, with pearson correlation value against the total score passed from r-table and cronbach's alpha higher than 0.6.

\subsection{Classic Assumption Test}

The results of the normality test analysis in Table 1 show that ASymp.Sig. (2-tailed) of 0.200> 0.05 . This means that the residual regression in this study is normally distributed. Furthermore from Table 2 it can be seen that the independent variables Collinearity Statistics Tolerance value greater than 0.100 , and VIF value less than 10. From the values that appear, then the conclusion that can be taken is the data does not occur multicolonierity problem. Test heterokedastisitas in 
Table 3 note that the significance value of all the influence of independent variables on absolute residual, greater than 0.05 , meaning there is no heteroscedasticity.

Table 1: Result of Normality Test

\begin{tabular}{|l|l|}
\hline Variable & Asymp. Sig. \\
\hline Residual Regression SubStructure I & 0,200 \\
\hline Residual Regression Substructure II & 0,200 \\
\hline
\end{tabular}

Table 2: Result of Multicolonierity Test

\begin{tabular}{|l|l|l|l|l|}
\hline Regression & \multirow{2}{*}{ Dependent Variable } & Independent Variable & \multicolumn{2}{|l|}{ Collinearity Statistics } \\
\cline { 3 - 5 } & & Tolerance & VIF \\
\hline Sub Structure I & Organizational Commitment & Locus of Control & 0,740 & 1,352 \\
\cline { 3 - 5 } & Self Efficacy & 0,740 & 1,352 \\
\hline \multirow{3}{*}{ Sub Structure II } & Employee Performance & Locus of Control & 0.568 & 1.759 \\
\cline { 3 - 5 } & Self Efficacy & 0.203 & 4.957 \\
\cline { 3 - 5 } & Organizational Commitment & 0.161 & 6.215 \\
\hline
\end{tabular}

Table 3: Result of Uji Heteroskedastisity Test

\begin{tabular}{|l|l|l|l|}
\hline Regression & Dependent Variable & Independent Variable & Sig. Value \\
\hline Sub Structure I & Absolut Residual 1 & Locus of Control & 0.544 \\
\cline { 3 - 4 } & & Self Efficacy & 0.076 \\
\hline Sub Structure II & Absolut Residual 2 & Locus of Control & 0.236 \\
\cline { 3 - 4 } & & Self Efficacy & 0.246 \\
\cline { 3 - 4 } & & Organizational Commitment & 0.335 \\
\hline
\end{tabular}

\subsection{Regression Analysis Equation I and II}

Regression analysis I (Sub Structure I) used to know how big effect of variable of Emotional Intelligence and Employee Creativity to Job Satisfaction variable either partially or simultaneously. Regression analysis II (Sub Structure II) used to know how big the effect of variable of Emotional Intelligence, Employee Creativity and Job Satisfaction to performance variable either partially or simultaneously. The path analysis results can be explained in Table 4.

Table 4: Result of Path Analysis

\begin{tabular}{|l|l|l|l|l|}
\hline Regression & Variable & Standardized Coefficients & t count & Sig \\
\hline Sub Structure 1 & Locus of Control & 0,256 & 4,219 & 0,000 \\
\cline { 2 - 5 } & Self Efficacy & 0758 & 12,493 & 0,001 \\
\hline \multirow{5}{*}{ Sub Structure 2 } & Locus of Control & $-0,086$ & $-2,219$ & 0,029 \\
\cline { 2 - 5 } & Self Efficacy & 0,341 & 5,345 & 0,000 \\
\cline { 2 - 5 } & $\begin{array}{l}\text { Organizational } \\
\text { commitment }\end{array}$ & 0,711 & 9,929 & 0,000 \\
\cline { 2 - 5 } & $\begin{array}{l}\text { Dependent Variable: Employee Performance } \\
\text { R Square = 0,952 F value = 384,537 Sig. =0,000 }\end{array}$ \\
\hline
\end{tabular}


Based on path analysis result, the following results can be obtained, as follows:

Equation 1:

$\mathrm{Y} 1=0,256 \mathrm{X} 1+0,758 \mathrm{X} 2+\epsilon 1$

Equation 2:

$\mathrm{Y} 2=-0,086 \mathrm{X} 1+0,341 \mathrm{X} 2+0,711 \mathrm{Y} 1+\epsilon 2$

The Model of path analysis result is explained in Figure 2.
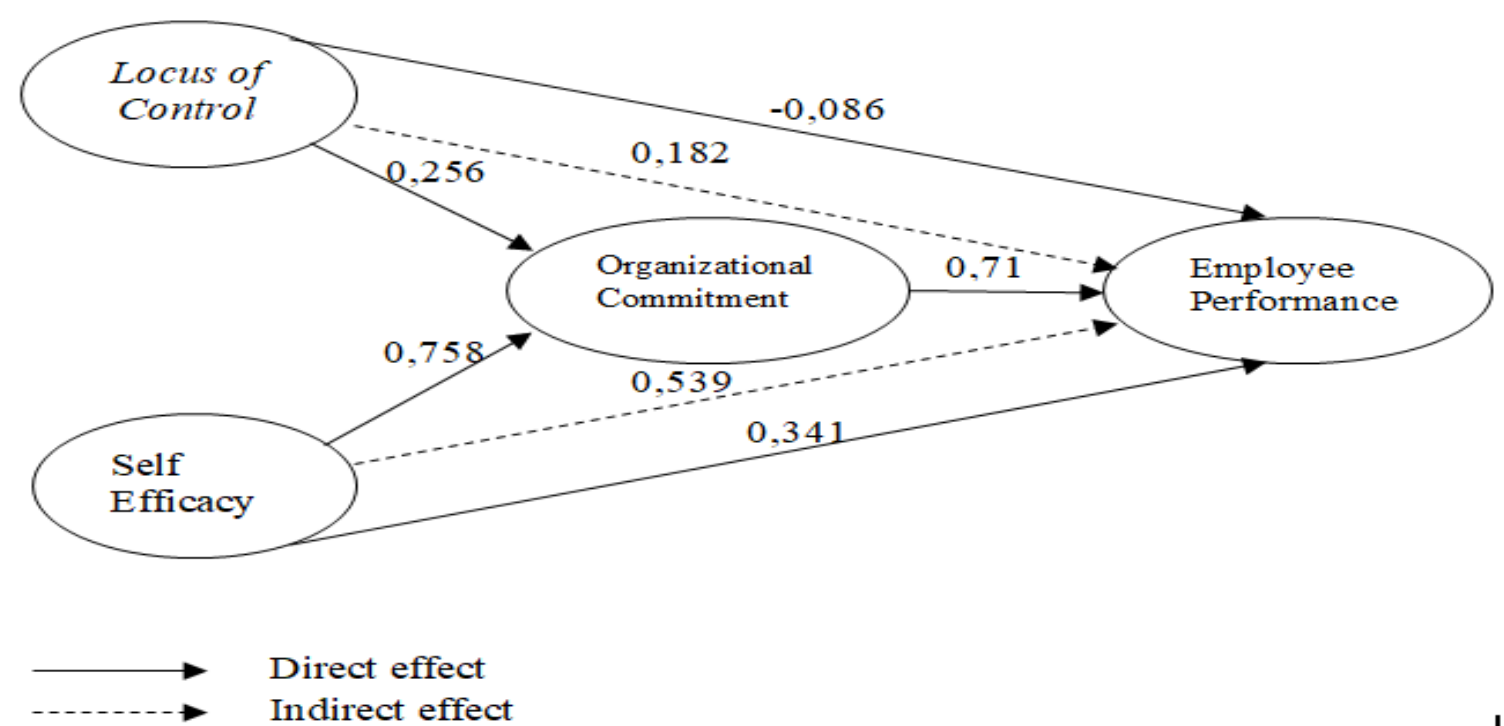

Figure 2: Model of Path Analysis Result

\subsection{Mediation / Intervening Test}

Testing the role of mediation in research done by using the calculation of sobel test, namely assessing the significance of indirect influence of locus of control and self efficacy to employee performance through organizational commitment.

The result of standard error calculation $(\mathrm{Sab})$ indirect effect is as follows:

$$
\begin{aligned}
& S a b=\sqrt{p 3^{2} s p 2^{2}+p 2^{2} s p 3^{2}+s p 2^{2} s p 3^{2}} \\
& S a b 1=\sqrt{1,030^{2} * 0,076^{2}+0,320^{2} * 0,104^{2}+0,076^{2} * 0,104^{2}} \\
& \text { Sab1 }=\mathbf{0 , 0 8 5} . \\
& \text { Sab2 }=\sqrt{1,030^{2} * 0,059+0,731^{2} * 0,104^{2}+0,059^{2} * 0,104^{2}} \\
& \text { Sab2 }=\mathbf{0 , 0 9 8} .
\end{aligned}
$$

Based on standart error (Sab) value above, we can calculate the t value of the indirect coefficient as follows : 


$$
\begin{aligned}
& t=\frac{a b}{s a b} \\
& t 1=\frac{0,182}{0,085} \\
& t 1=\mathbf{2 , 1 3 0 .} \\
& t 2=\frac{0,539}{0,098} \\
& \mathrm{t} 2=\mathbf{5 , 5 2 7} .
\end{aligned}
$$

The value of t count of 2.130 and 5.527 is compared with the value of $t$ table 1.671. Because the value of $t$ count $>t$ value table it can be concluded there is influence of mediation or intervening Locus of Control and Self Efficacy on Employee Performance through Organizational Commitment

\section{Discussion}

Locus of control is very important to note, because the relationship is very closely with the performance and other individual variables. Locus of control is also believed to be closely related to job satisfaction, job involvement, organizational commitment, and leadership ((Silva, 2006). The results of this study have been conducted in accordance with the results of previous studies. Several previous studies have shown that workers with internal locus of control will have high organizational commitment, and workers with high organizational commitment will tend to be more productive ((Agho, Mueller, \& Price, 1993); (Adeyemi-Bello, 2003); (Aubé, Rousseau, \& Morin, 2007)

Organizational commitment is degree to which an employee sides with a particular organization and its goals, and intends to maintain membership within the organization. Organizational commitment in this case the Regional Secretariat of Blora Regency as an organization to see how a civil servant can pour out his heart, mind and energy by trying to do the best and have the desire to survive in the organization. Based on previous research on the influence of self efficacy factors on long-distance workers' organizational commitment, self efficacy has a positive causal relationship to organizational commitment (Hariyanto, 2001). According to Haryanto (2001) organizational commitment as one of the attitudes that workers have the better if the self-efficacy consideration of the workers is getting better too. The result of previous research stated that the increase of self efficacy of civil servants will be followed by increasing the commitment of civil servants, and the decrease of self efficacy of civil servants followed by the decreasing of civil servants. Previous studies have stated that Self Efficacy has a strong influence on Employee Performance. According to (Noviawati \& Witjaksono, 2016) self efficacy will encourage someone to work more spirit to achieve optimal results in their performance.

As it has been described above that the Locus of Control (LoC) is a personality attribute that reflects the degree to which employees perceive events that occur under control awareness 
(internal control or internal locus) or under stronger control (self-control container) from outside or external locus). The results of this study did not indicate the influence of locus of control on the performance of employees of the Regional Secretariat Environment of Blora Regency. The influence of Locus of Control on Employee Performance is negative which means the improvement of locus of control will decrease employee performance. This is indicated that the employees tended to have external locus of control, means the success influenced by external factors such as luckiness or environment effects. Previous research by (ISWARI, 2013) concluded that locus of control didn't have significant effect toward performance.

Organizational commitment has a positive impact on employee performance in accordance with the previous. In other words, employees with a commitment to a high organization will perform better. Organizational commitment is an attitude that reflects employees' loyalty to the organization and the ongoing process in which members of the organization express their concern for the organization and its continued success and progress (Luthans \& Jensen, 2005). Organizational commitment basically emphasizes how the relationship of employees and work units create an attitude that can be viewed as a sense of attachment to the philosophy and work unit, where employees will hold firmly wholeheartedly and promise to carry out the duties that must be carried out in accordance with the principles set by a group of people or bodies who are bound in a joint venture to achieve certain goals. Previous research is essentially that Organizational Commitment has a great influence on Employee Performance (Rakhmawati \& Darmanto, 2014), (Mubarak \& Darmanto, 2015). In this study it can be concluded that there is a positive and significant influence Organizational Commitment (Y1) variable to Employee Performance (Y2). The results reinforce the theory that organizational commitment is an important topic in a number of studies and is an important variable in understanding worker behavior of workers within an organization (Mowday et al., 1982).

\section{Conclusion}

Locus of control and self efficacy are personality traits which have positive and significant effect on organizational commitment in developing employee performance.

Organizational commitment is an important topic in a number of studies and is an important variable in understanding worker behavior of workers within an organization due to its role in mediating personality towards performance.

\section{References}

[1] Adeyemi-Bello, T. (2003). The impact of leader characteristics on the performance of organizational members: an exploratory study. Work Study, 52(6), 286-289.

[2] Agho, A. O., Mueller, C. W., \& Price, J. L. (1993). Determinants of employee job satisfaction: An empirical test of a causal model. Human relations, 46(8), 1007-1027.

[3] Allport, G. W. (1961). Pattern and growth in personality.

[4] Aubé, C., Rousseau, V., \& Morin, E. M. (2007). Perceived organizational support and organizational commitment: The moderating effect of locus of control and work autonomy. Journal of managerial Psychology, 22(5), 479-495. 
[5] Brown, S. P., \& Peterson, R. A. (1993). Antecedents and consequences of salesperson job satisfaction: Meta-analysis and assessment of causal effects. Journal of marketing research, 30(1), 63.

[6] Darmanto, S. (2012). Peran Sifat Personalitas (Personality Traits) Dalam Mendorong Minat Berwirausaha Mahasiswa. Media Ekonomi Dan Manajemen, 25(1).

[7] Entrialgo, M., Fernández, E., \& Vázquez, C. J. (2000). Psychological characteristics and process: the role of entrepreneurship in Spanish SMEs. European Journal of Innovation Management, 3(3), 137-149.

[8] Hisrich, R., Langan-Fox, J., \& Grant, S. (2007). Entrepreneurship research and practice: a call to action for psychology. American psychologist, 62(6), 575.

[9] Hyatt, T. A., \& Prawitt, D. F. (2001). Does congruence between audit structure and auditors' locus of control affect job performance? The Accounting Review, 76(2), 263-274.

[10] ISWARI, T. I. (2013). PENGARUH ORGANIZATIONAL-PROFESSIONAL CONFLICT TERHADAP PROFESSIONAL JUDGMENT AKUNTAN PUBLIK DENGAN TIPE KEPRIBADIAN, GENDER, DAN LOCUS OF CONTROL SEBAGAI VARIABEL PEMODERASI. [Yogyakarta]: Universitas Gadjah Mada.

[11] Luthans, K. W., \& Jensen, S. M. (2005). The linkage between psychological capital and commitment to organizational mission: A study of nurses. Journal of Nursing Administration, 35(6), 304-310.

[12] Macik-Frey, M., Quick, J. C., \& Nelson, D. L. (2007). Advances in occupational health: From a stressful beginning to a positive future. Journal of Management, 33(6), 809-840.

[13] Mowday, R. T., Porter, L. W., \& Steers, R. M. (1982). Employee-organization linkage. The psychology of commitment absenteism, and turn over_Academic Press Inc. London.

[14] Mubarak, A., \& Darmanto, S. (2015). Pengaruh Gaya Kepemimpinan Transformasional Dan Budaya Organisasi Terhadap Kinerja Pegawai Dengan Komitmen Organisasi Sebagai Variabel Intervening (Studi pada PNS di Kecamatan Watukumpul Kabupaten Pemalang). MAKSIMUM, $5(1)$.

[15] Noviawati, D. R., \& Witjaksono, A. D. (2016). Pengaruh Self Efficacy Terhadap Kinerja Karyawan Dengan Motivasi Sebagai Variabel Intervening (Studi Pada Karyawan Divisi Finance Dan Divisi Human Resource Pt. Coca-Cola Distribution Indonesia, Surabaya). Jurnal Ilmu Manajemen (JIM), 4(3).

[16] Patten, D. M. (2005). An analysis of the impact of locus-of-control on internal auditor job performance and satisfaction. Managerial Auditing Journal, 20(9), 1016-1029.

[17] Porter, L. W., Steers, R. M., Mowday, R. T., \& Boulian, P. V. (1974). Organizational commitment, job satisfaction, and turnover among psychiatric technicians. Journal of applied psychology, 59(5), 603.

[18] Rakhmawati, D., \& Darmanto, S. (2014). Pengaruh Gaya Kepemimpinan Transformasional, Kepercayaan, Kerjasama Tim Terhadap Komitmen Organisasi Untuk Meningkatkan Kinerja Karyawan (Studi Kasus di Perum Perhutani Kesatuan Bisnis Mandiri Industri Kayu Brumbung Satu Jawa Tengah). Media Ekonomi Dan Manajemen, 29(1).

[19] Robbins, S. P. (1993). Organizational Behavior: Concepts, Controversies, and Applications, 6/E: Capital Cities/ABC Video Enterprises, Incorporated.

[20] Rotter, J. B. (1966). Generalized expectancies for internal versus external control of reinforcement. Psychological monographs: General and applied, 80(1), 1.

[21] Silva, P. (2006). Effects of disposition on hospitality employee job satisfaction and commitment. International Journal of Contemporary Hospitality Management, 18(4), 317-328.

[22] Susetyo, D., \& Lestari, P. S. (2014). Developing entrepreneurial intention model of university students: an empirical study on university students in Semarang Indonesia. International Journal of Engineering and Management Sciences, 5(3), 184-196. 
[23] Taormina, R. J., \& Lao, S., K. (2007). " Measuring Chinese Entreprenurial Motivation: Personality and enviromental influences". International Journal of Entrepreneurial Behavior \& Research, 13, 200-211.

[24] Tett, R. P., \& Meyer, J. P. (1993). Job satisfaction, organizational commitment, turnover intention, and turnover: path analyses based on meta-analytic findings. Personnel psychology, 46(2), 259-293.

*Corresponding author.

E-mail address: susiyantievi@ gmail.com/susetyodarmanto@ untagsmg.ac.id 